\section{Født til å løpe?}

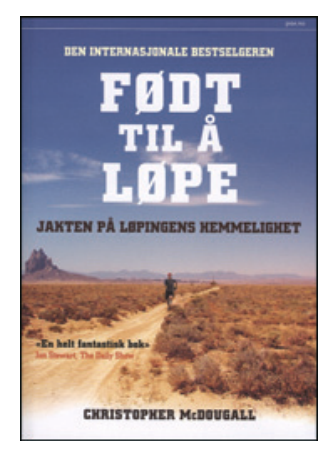

Christopher McDougall

\section{Født til å løpe}

Jakten på løpingens hemmelighet. $326 \mathrm{~s}$

Oslo: Pax Forlag, 2012.

Pris NOK 299

ISBN 978-82-530-3488-1
Mange bøker er forfattet omkring temaet løping, og en rekke legender er grundig omtalt og analysert opp gjennom tidene. Løping har også vært gjenstand for vitenskaplige vurderinger langt ut over de mer åpenbart medisinske, fysiologiske og biomekaniske særtrekkene ved denne «uraktiviteten». Forfatteren, utenrikskorrespondent og dedikert løpeentusiast, signaliserer allerede i tittelen en ambisjon med sitt bokprosjekt. Min forventning til en avsløring av hemmeligheter knyttet til denne aktiviteten er ikke helt uten skepsis. Boken har dog brakt forfatteren til topps på bestselgerlistene og inn i lenestoler hos glorifiserte talkshowverter verden over. Det er trolig ikke uten grunn.

Denne reisen, for det er en slags reisefortelling forfatteren tar oss med på, starter forventningsfullt hos en profilert idrettsmedisiner. Frustrasjon over smertene i foten har ført ham dit. Forfatterens fargerike beskrivelse av lykkefølelsen han opplever gjennom lange turer i fri dressur illustrerer på en gjenkjennende måte desperasjonen han opplever ved fraværet av disse daglige adrenalinkickene. Fallhøyden er urovekkende stor for den aldrende idrettsmedisineren når han lakonisk beskriver hvor idiotisk det er at en voksen mann på $193 \mathrm{~cm}$ og $105 \mathrm{~kg}$ gir seg i kast med løping. Terapianbefalingen faller heller ikke i smak: «Kjøp deg sykkel.» Krigsreporteren og researchjournalisten våkner til liv, og her starter en reise med så mange og merkelige avstikkere, sidegater og blindveier at jeg mer enn en gang glemmer både himmelretning og mål. Takket være en befriende fortellerkunst og en sjelden fantasifull evne til å knytte avstikkerne sammen, vever han en rød tråd. Forfatterens iver etter å rettferdiggjøre løping som noe mer enn en måte å forflytte seg på, åpner for interessante teorier. Fylogenesen tolkes i lys av mennesket som et løpende vesen - morsomt og fantasifullt, underholdende er det definitivt, men når dette forsøksvis belegges med vitenskap får min primære skepsis næring. Gjennom boken blir ideen klarere, løpsbølgen på 1970- og 80-tallet beskrives med historisk korrekthet og stor detaljkunnskap. Kommersialiseringen, representert av de store skoprodusentene, trer gummierte støtdempere over den legemsdelen som gjennom fylogenesen har gitt men- nesket den ultimate støtdemperen: vår egen fot. Her beskrives industrien, som i sin iver etter å suge kapital ut av løpshungrige horder, tvinger mennesket til å dyrke en helt annen aktivitet: den kommersielt baserte joggebølgen er et faktum. Vi skulle ikke lenger løpe lett på forfoten, den plyometriske fotavviklingen ble byttet ut med flatt fotisett og rullesteg. Behovet for støtdemping var dermed definert, nye modeller og avanserte prinsipper for støtdemping avløste hverandre i årenes løp.

Denne boken handler om det ekstreme: ultramaraton. Mennesket alene, fri tankeflyt gjennom landskapet, utmattelse i et endorfinbad - ikke ulikt andre former for kjemisk stimulering drevet av et behov, en avhengighet, en sykdom. Forfatteren tar oss inn i den tankeverdenen som $\mathrm{i}$ all sin enkelhet og kompleksitet driver oss til det ekstreme.

Boken er allerede en kultbok i den forstand at den har dannet mønster for nye tanker og subkulturer. Barfotløping er en ny trend, og noen av trendsetterne har funnet sitt rasjonale i denne teksten.

Verken joggesko eller løpeerfaring er noe krav for å nyte boken. Den er lettlest, humoristisk og velskrevet i en norsk oversettelse som også står seg gjennom det meste av den medisinske terminologien. Ikke la deg friste til å lese denne boken som en fagbok, de logiske bristene vil bare irritere en akademisk hjerne. Argumenteringen er forsøksvis vitenskapsbasert og preges av en nærmest religiøs overbevisning. La deg heller ikke forlede til å tro at alle mennesker er født til å løpe. Noen mennesker er sikkert født til å løpe, mens mange definitivt skal ta imot rådet om å anskaffe en sykkel.

\section{Ove Talsnes}

Ortopedisk avdeling

Sykehuset Innlandet 